\title{
La documentación fotográfica del 11-M como demanda cívica ${ }^{1}$
}

\author{
Rafael GARCÍA ALONSO \\ Universidad Complutense de Madrid \\ rgarc01@pdi.ucm.es
}

Recibido: 04-06-2013

Aceptado: 18-07-2014

\section{Resumen:}

Poco después de los atentados cometidos en Madrid, el 11 de marzo de 2004, por la organización Al Qaeda diversos fotógrafos documentaron los hechos. Las fotografías formaron parte relevante de los denominados "altares espontáneos" que surgieron en los lugares de los hechos. En este artículo se realiza un recorrido iconográfico y cronológico sobre distintos tipos de fotografías: de auxilio, de heridos en las salas de espera, de los trenes, de ofrendas, de concentraciones, de manifestaciones, de autoridades y monumentos. Se pone de manifiesto, además, como el movimiento cívico espontáneamente surgido así como, más tarde, el 15 de diciembre de 2004, el discurso leído por la Asociación 11M. Afectados del Terrorismo (en adelante, AAT) en el Congreso de los Diputados, entrañan un cuestionamiento de las prácticas políticas llevadas a cabo por la Comisión de investigación, y reivindican una conexión mayor a la usual entre la vida política institucionalizada y la ciudadanía.

Palabras clave: Fotografía; uso documental; uso artístico; racionalización; sociedad del riesgo; comunidad (Gemeinschaft); sociedad civil; legitimidad.

\section{The photographic documentation of 11-M as civic demand}

\begin{abstract}
:
Shortly after the attacks carried out by the Al Qaeda in Madrid on March 11, 2004 various photographers documented the facts. The photographs were an important part of the so-called "spontaneous shrines" that emerged in the crime scenes. This article gives an iconographic and chronological view
\end{abstract}

\footnotetext{
${ }^{1}$ Una primera versión de este artículo fue presentada en el Congreso "Las artes y los discursos ideológicos del poder tecnoeconómico y político en las sociedades avanzadas. El caso español”, dirigido por el Profesor Juan Antonio Roche y celebrado en Alicante los días 20 y 21 de octubre de 2011.

El Archivo del Duelo se halla constituido por 70.000 unidades donde se incluyen fotografías digitales y analógicas, documentos manuscritos e impresos en papel, objetos varios, mensajes electrónicos, y grabaciones sonoras y audiovisuales. Se encuentra depositado en el Archivo Histórico Ferroviario situado en el Museo del Ferrocarril de Madrid. Esta institución depende de la Fundación de Ferrocarriles Españoles. El autor agradece la colaboración de estas instituciones, especialmente de Doña Raquel Letón Ruiz y de Doña Leticia Martínez García; así como del diario El País, especialmente a Don Gabriel Bravo Benito.
} 
about different types of photographs: relief, injured in waiting rooms, the trains, offerings, mergers, demonstrations, authorities and monuments.

It shows as well how the civic movement that emerged spontaneously and December 152004 speech read by an association of victims in the Congress of Deputies poses a challenge to the political practices carried out by the investigation Commission and claims a high connection between institutionalized political life and citizenship.

Keywords: Photography; documentary use; artistic use; rationalisation; risk society; community (Gemeinschaft); legitimacy; civil society.

\section{Referencia normalizada}

García Alonso, R. (2014): “La documentación fotográfica del 11-M como demanda cívica”, Política y Sociedad, 51 (3), pp. 757-788.

Sumario: Introducción. 1. Racionalización y modernidad. 2. Fotografías de auxilio inmediato. 3. Fotografías de heridos fuera del lugar de la explosión. 4. Fotografías de los trenes. Fotografías de cadáveres. 5. Fotografías de ofrendas. El impulso comunitario. 6. Fotografías de ofrendas. El impulso personal. 7. Fotografías de concentraciones. 8. Fotografías de manifestaciones. 9. Fotografías de autoridades y monumentos. 10. Conclusiones. Bibliografía y filmografia.

“Mañana saldré de casa como lo hacías tú, para continuar tu viaje”. (Inscripción en el Monumento homenaje a las víctimas del 11-M).

El 11 de marzo de 2004 (11-M) once bombas estallaron en las estaciones de tren de El Pozo, Santa Eugenia y Atocha. Las dos primeras situadas en barrios de las afueras de Madrid; la última en pleno centro de la ciudad, en un núcleo de comunicaciones. Como consecuencia de los atentados, más tarde reivindicados por el grupo Al Qaeda, 191 personas murieron y más de 1400 quedaron heridas de diversa consideración. Nos proponemos en este artículo reflexionar sobre algunas fotografías relacionadas con aquella masacre. Nos basaremos principalmente en imágenes publicadas en el libro editado por el Consejo Superior de Investigaciones Científicas (CSIC) sobre el proyecto de investigación Archivo del Duelo (Sánchez Carretero: 2011a), y en otras que pudimos encontrar en la prensa y en internet. Habremos de mencionar, además, las denominadas fotos "censuradas" que han circulado clandestinamente en la red. Realizaremos un recorrido desde las horas inmediatas al atentado hasta la apertura al público de dos monumentos en recuerdo de las víctimas. Nos detendremos en imágenes tomadas en actos de duelo, homenajes, concentraciones y manifestaciones que siguieron al crimen. Nos preguntaremos por las características de las fotos y por su significación social. Nuestra primera hipótesis de trabajo consiste en que las imágenes, de carácter documental, muestran una sociedad convencida de su derecho a considerar la política como una actividad democrática que no puede anquilosarse en su marco institucional. En segundo lugar, defenderemos que si bien en las fotografías del 11-M la función comunicativa primaba sobre la estética, ésta última era relevante. 
Los dos usos característicos de la fotografía son el documental y el artístico. Aunque sean obviamente complementarios, para nuestro objetivo es interesante tener en cuenta las consideraciones formuladas en 1929 por los lingüistas del denominado Círculo de Praga (Circulo de Praga, 1970: 31). En el uso documental de la fotografía predomina la función comunicativa -en la que el signo remite a un significado exterior al mismo. En este caso importa ante todo el significado semántico que nos ayuda a plantearnos qué se comunica con la imagen. En el uso artístico de la fotografía se impone la función poética -en la que la conciencia se dirige al propio signo, convirtiéndose éste en objeto de atención estética de tal manera que toma especial relieve la dimensión formal en factores como composición, ritmo, equilibrio, etc. En las fotos del 11-M el uso documental es predominante con excepción de las fotos sobre el monumento dedicado a las víctimas inaugurado en marzo de 2007 junto a la estación de Atocha. Una de las razones para ello, pero no la única, es que para tomar estas últimas fotos se contaba con la tranquilidad de no verse presionado por captar un momento irrepetible; el fotógrafo se podía tomar el tiempo que fuera necesario. Por el contrario, las fotos de carácter documental, pretenden registrar momentos fugitivos, una determinada escena, un gesto...

La documentación fotográfica del $11-\mathrm{M}^{2}$ adquiere, de esa forma, tres misiones. En primer lugar, gracias a su carácter de registro mecánico de la realidad, permite la comunicación de algo que ha ocurrido ante la cámara. Se convierte en prueba testifical. En segundo lugar, sirve como apoyo a la memoria puesto que sus imágenes pueden ser visualizadas en el futuro siempre que se disponga de acceso a las mismas. De hecho, el proyecto El archivo del duelo, no sólo ha recogido 2482 fotografías sino que este medio de comunicación ha constituido una herramienta fundamental para poder realizar tanto la labor de catalogación como para mostrar públicamente sus resultados. En tercer lugar, de especial relevancia en nuestro planteamiento, las imágenes del 11-M pretenden, desde el primer momento, tener alcance performativo como conducta cívica, puesto que se recurre a ella como una herramienta adecuada de respuesta frente al ataque terrorista; en efecto, se consideró que era indispensable testimoniar lo que estaba ocurriendo así como la reacción ciudadana. La fotografía era usada como arma cívica y pacífica contra la barbarie terrorista que agredía a la sociedad madrileña. Los antropólogos del CSIC, los periodistas gráficos e incluso quizá los viandantes que tomaron fotos, recurrieron de modo inmediato a la fotografía como respuesta a las preguntas, ¿qué podemos hacer?, ¿cómo podemos ayudar?, encontrando en la respuesta latente, “documentar

\footnotetext{
${ }^{2}$ Es, en su asepsia, muy convincente la siguiente definición de fotografía de Román Gubern: “Tecnología comunicativa que permite fijar ópticamente un fragmento del universo visual en un tiempo dado, para perpetuarlo bidimensionalmente a través del tiempo y del espacio y procurar a su(s) destinatario(s) una experiencia óptica vicarial relativa a aquella escena matricial alejada en el tiempo y acaso en el espacio” (Gubern, 1987: 154).
} 
los hechos”, una opción valiosa. Se consideró necesario testificar lo condenado a hacerse ausente con el paso del tiempo.

\section{Racionalización y modernidad}

Los atentados afectaron a trenes llenos de personas que acudían a primera hora de la mañana a sus quehaceres cotidianos. Desde el punto de vista de los terroristas no hay duda de que se pretendía hacer el mayor daño posible actuando de forma indiscriminada sobre una población absolutamente desprevenida e indefensa. Para comprender mejor el suceso es pertinente señalar a continuación algunas características del mundo moderno sobre las que han reflexionado diversos sociólogos.

El servicio de transporte ferroviario constituye un caso prototípico del proceso de racionalización de las sociedades contemporáneas. Supone una coordinación de medios y tiempos que potencia la exactitud y, tal como expuso Georg Simmel en 1903, el espíritu calculador. El urbanita debe moverse diariamente en el trasiego ciudadano pendiente del reloj. Es significativo a este respecto que se conozca con exactitud el momento de la explosión en cada uno de los trenes: las 7,39 justo antes de entrar en la estación de Atocha; las 7,41 en la estación de El pozo del tío Raimundo; las 7,42 en la estación de Santa Eugenia. La racionalización se halla presente tanto en los hábitos de los habitantes como en el funcionamiento del sistema. Se da por supuesto que éste último, salvo anomalías, funcionará de acuerdo a un plan previsto reforzando que el comportamiento y la mentalidad del ciudadano se adecue a dichas previsiones. Se anuncia por diversos medios, por ejemplo, la temperatura exterior, el tiempo de los recorridos y las correspondencias de transporte que podrán efectuarse. Sumido en tal ordenado tumulto cotidiano, en el urbanita escribía Simmel, domina el entendimiento y crece el espíritu calculador, hasta el punto que "el hombre puramente racional es indiferente frente a todo lo auténticamente individual" (Simmel, 1986: 249). Como viajero de trenes, el urbanita recurre a numerosas estrategias para mantener, si lo desea, su individualidad y aislamiento respecto a los otros viajeros. Esta normalidad es la que estalla literalmente en los atentados del 11M. Con la paradoja de que también los terroristas han actuado racional y calculadoramente en sus propósitos asesinos. En primer lugar, en la organización material de los atentados intentando ser lo más letales posibles. En segundo lugar, procurando incidir en la política española ${ }^{3}$. Finalmente, en cuanto no parece disparatado pensar

${ }^{3}$ Según Fernando Reinares, la decisión de atentar en España se remonta hasta 2001, mucho antes, por tanto, de que se diera la guerra de Irak y de que se conociera el contexto electoral español concreto del 2004. Sin embargo, los terroristas tenían entre sus objetivos “condicionar a nuestra opinión pública, a fin de incidir sobre las decisiones gubernamentales en política exterior, independientemente de que hubiese elecciones generales” (Reinares, 2014: 189) 
que los ataques terroristas formaban parte de una puesta en escena internacional destinada a mostrar la capacidad destructiva del grupo Al Qaeda. ${ }^{4}$

\section{Fotografías de auxilio inmediato}

¿Qué nos muestran las fotografías a las que hemos tenido acceso? Aunque más adelante incidiremos en ello, conviene señalar ya que hay una única foto en el escenario del horror en la que aparece una mujer muerta con el rostro descubierto; en ninguna hay despojos humanos. En ellas se observan personas que están siendo auxiliadas por civiles (Imagen 1) o por servicios públicos tales como policía, bomberos, trabajadores del ayuntamiento o instituciones sanitarias. (b) Se ha procurado captar el hecho de forma discreta sin que los fotografiados lo advirtieran. De ahí, que en ningún caso hallamos localizado fotos en las que los sujetos se hallen posando. Es significativo que incluso en la única toma que hemos encontrado en la que un herido sabe probablemente que está siendo fotografiado de cerca, evita mirar al objetivo. (c) En general, parecen haberse restringido, por lo menos en su difusión, escenas truculentas como rostros ensangrentados o cuerpos heridos. (d) En algunas imágenes pueden ser advertidos ecos de la iconografía cristiana, tal como sucede con el tema de "la piedad" o del "descendimiento" (Imagen 2). (e) En estas fotografías, la función comunicativa prima sobra la estética. Quizás en sintonía, como escribió alrededor de 2001 Susan Sontag, con el conocimiento tácito de que "la fotografía que ofrece testimonio de lo calamitoso y reprensible es muy criticada si parece «estética», es decir, si se parece demasiado al arte" (Sontag, 2010: 68).

Un tema polémico, empero, es si los fotógrafos han cumplido con el respeto a la intimidad de los heridos y de sus familiares. En efecto, como se quejaba Pilar Manjón el 15 de diciembre de 2004, en tanto que representante de la Asociación 11M. Afectados del Terrorismo (AAT), en su discurso en el Congreso de los Diputados, en la difusión de las imágenes no se había tenido en cuenta la voluntad de los afectados ni se había pedido "permiso para la utilización de nombres, fotografías e historias que forman parte de la privacidad de las familias” (AAT, 2005: 34).

${ }^{4}$ Como escribió Ulrich Beck tras los atentados contra las Torres Gemelas de Nueva York del 11 de septiembre de 2001 por parte del grupo Al Qaeda, en aquellos hechos -y también, podemos añadir, en el 11-M- se daba una mezcla de modernidad y arcaísmo en el que se entremezclaban estrechamente "el antimodernismo fanático, el antiglobalismo y el pensamiento y la acción globales modernos” (Beck, 2003: 27). Beck señala entre otros aspectos clave, el cálculo realizado por los terroristas en 2001 de tal modo que se transmitiera en directo a todo el mundo el choque del segundo avión contra las Torres Gemelas (Beck, 2003: 46). 


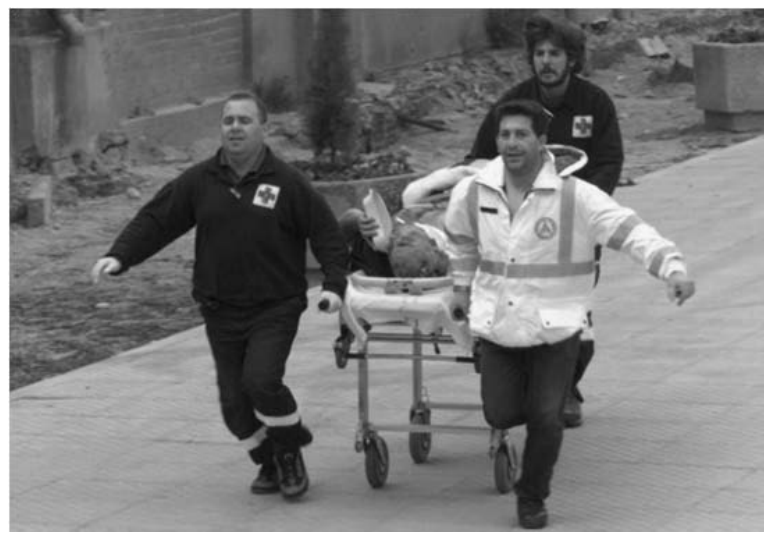

Imagen 1

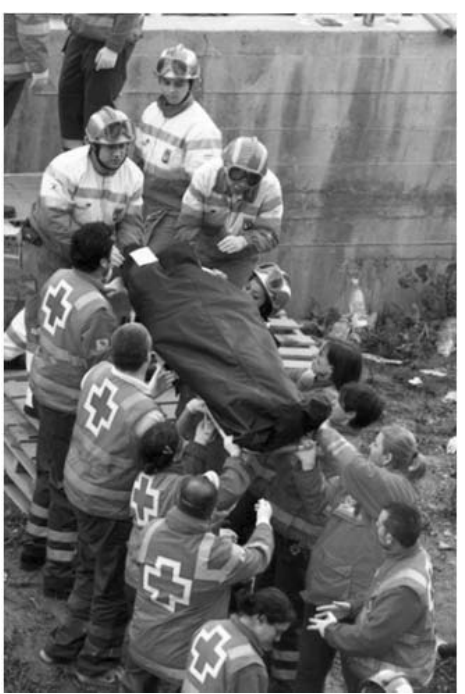

Imagen 2

Por otra parte, las fotos testimonian cómo en esas primeras horas de sorpresa y desolación, se produjo un impulso espontáneo de solidaridad que rompe con el citado aislamiento respecto a los demás al que propende el habitante de las ciudades cuando viaja solo. También en este caso, la obligación ciudadana tácita y legal de auxilio al perjudicado en situaciones excepcionales parece haberse cumplido.

Pero, justamente en este aspecto, la actuación de los fotógrafos quedaba sometida a un dilema peculiar. ¿Qué debían hacer?, ¿documentar lo que estaba ocurriendo de acuerdo con su profesión o ayudar a remediar en la medida de sus posibilidades la tragedia que allí estaba ocurriendo, arrimando el hombro en unas circunstancias excepcionales en las que cualquier colaboración era oportuna? En uno de los cortometrajes de la película documental Madrid $11 \mathrm{M}$. Todos íbamos en ese tren aparece la queja de una mujer ante un fotógrafo que "estaba nada más a su trabajo", fotografiando sin parar hasta que le apostrofaron solicitando su ayuda. Fue inevitable que, en aquel momento, reapareciera este viejo debate que enfrenta al profesional cazador de imágenes, según la conocida metáfora, con el ciudadano que considera que, en tal situación, la prioridad era la ayuda a los afectados ${ }^{6}$.

5 “Víctima cero", dirigido por Miguel Ángel Nieto, en Barbadillo et al, 2004. Todos íbamos en ese tren.

${ }^{6}$ Como señaló Norbert Elias en 1956, compromiso y distanciamiento son dos extremos entre los que oscila la vida de los adultos, Ahora bien, "el margen de las variaciones indivi- 


\section{Fotografías de heridos fuera del lugar de la explosión}

Un segundo momento que puede apreciarse en las fotos es el referido a escenas tomadas en la calle. También en esta tipología se cumplen las características que hemos mencionado en el apartado anterior. En algunos casos, los heridos están siendo introducidos en una ambulancia, entrando en hospitales, siendo ayudados por civiles o permanecen en la acera en situaciones de confusión. Es probable que haya sido más difícil para los fotógrafos mantener la discreción y el decoro en aquellos recintos cerrados donde durante cierto tiempo los afectados permanecieron apoyados en las paredes o tendidos en el suelo.

Seguramente algunas víctimas fueron conscientes de la presencia del fotógrafo; algo quizás percibido como fútil en tal situación. Buena parte de las fotos están tomadas de tal modo que el rostro de quienes en ellas están presentes no es visible, o está suficientemente lejano como para ser reconocido. Son imágenes en las que se transparenta la confusión, el desconcierto, la vulnerabilidad, el "vagar sin rumbo" (AAT, 2005: 51) de los allegados en busca de noticias a los que se refería Manjón en su discurso (Imagen 3).

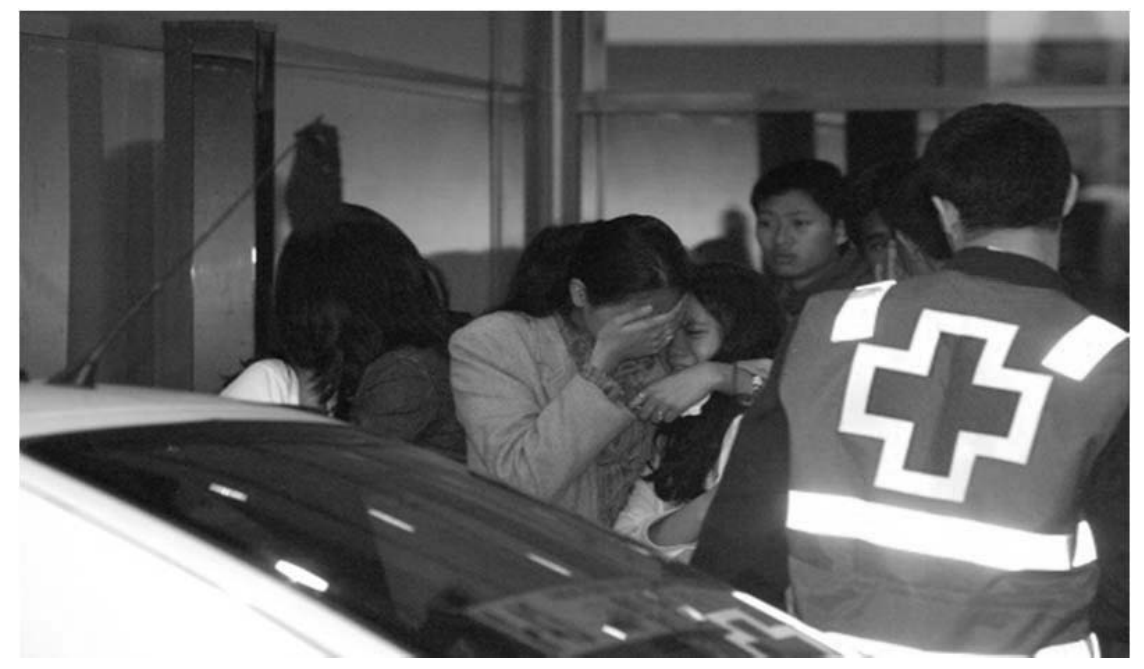

Imagen $\square$

duales del distanciamiento está supeditado a los patrones sociales del distanciamiento" (Elias, 1990: 13). 
Respecto a la situación en distintos pabellones públicos, la Asociación 11-M. Afectados del Terrorismo manifestó en el citado discurso que el sufrimiento se vio incrementado por la "descoordinación entre los diferentes servicios de atención" (AAT, 2005: 39), por la falta de rigor al seleccionar el perfil de muchos de los profesionales que atendieron a las familias de las víctimas y por la presencia fugaz "de cargos institucionales en el caos de Ifema (...que...) si acaso, vinieron con el tiempo justo para hacerse la foto. Les adivinamos de pasada, desde lejos” (AAT, 2005: 40). Por lo que concierne al uso de la fotografía, se trata de una queja ante la manipulación de los damnificados por parte de algunos políticos como medio para conseguir un fin que, de forma especialmente mezquina, hace de la política instrumento para la presentación pública. De ahí que suponga un tratamiento indigno de acuerdo a la célebre formulación kantiana de 1785 en la Fundamentación de la metafísica de las costumbres (Kant, 1986: 82-83), según la cual lo que dota de dignidad a la existencia del hombre es que ésta sea considerada como fin en sí mismo y no solo como medio.

Es significativo que las imprecaciones contra los terroristas sean relativamente escasas en las quejas de los damnificados. Como si se reconociera la irrelevancia y la imposibilidad de establecer cualquier tipo de intercambio verbal racional con ellos. Por el contrario, la batería de diez demandas cívicas que el discurso pronunciado por Manjón exigía en sus conclusiones, va destinado a reclamar la mejora del funcionamiento del Estado de Derecho en el afrontamiento de esta catástrofe: comisión de investigación independiente, juicios transparentes, uso ético por parte de los medios de comunicación de las imágenes del atentado... Concluían con la demanda en la vida sociopolítica de verdad, justicia y reparación. De esta forma, este texto ponía de relieve la insuficiencia de la racionalización (\# I) en la prevención del terrorismo y en la atención a sus víctimas.

\section{Fotografías de los trenes. Fotografías de cadáveres}

La magnitud de los sucesos produjo daños materiales espectaculares en los trenes. En algunas fotos (Imagen 4) se aprecian vagones reventados en diversos lugares. En imágenes tomadas desde lejos vemos a los servicios públicos realizar diversos trabajos después de que se evacuaran los heridos. Las fotos de interiores no reflejan el caos vivido por las víctimas: cristales rotos, cadáveres, fragmentos de cuerpos mutilados, sangre o jirones de ropa. Aun así, asépticas en la medida de lo posible, permiten evocar el horror de la destrucción salvaje. De nuevo, la función comunicativa es la dominante. 


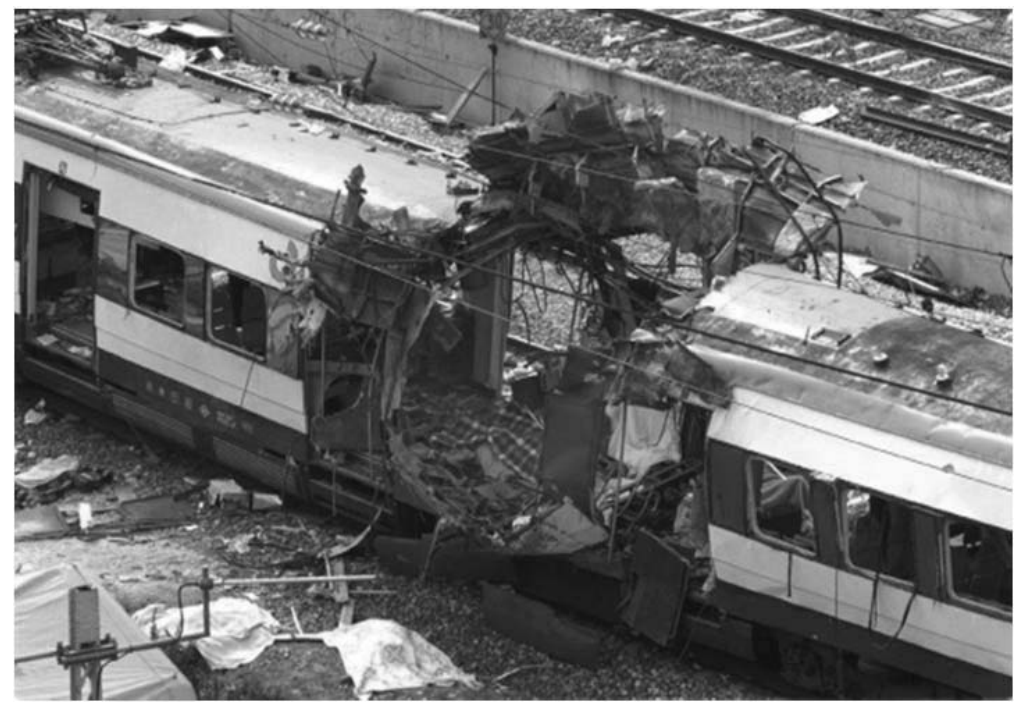

Imagen 4

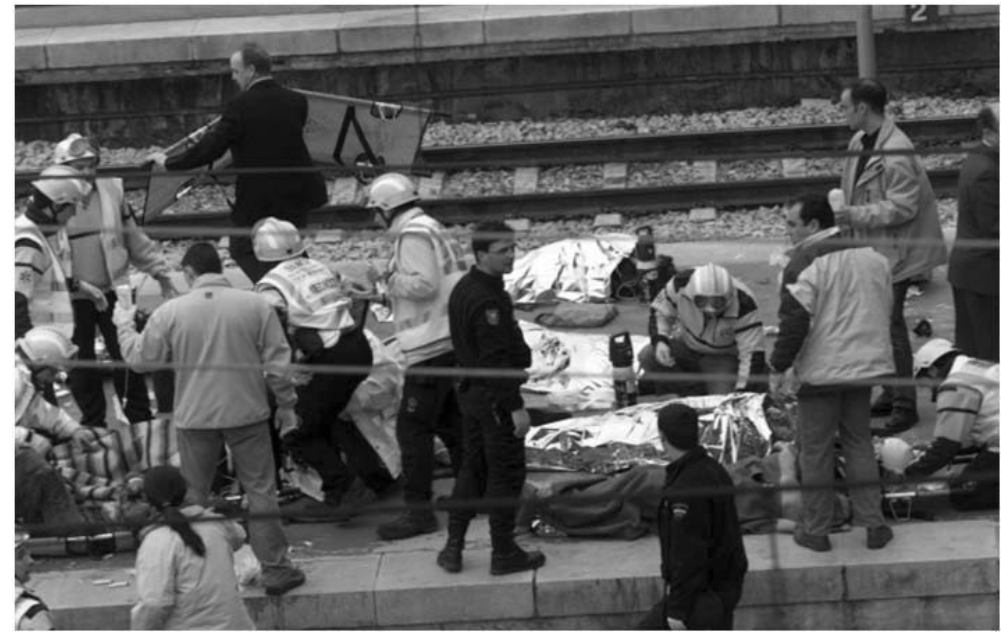

Imagen 5

Pese a ello, algunas imágenes pueden resultar al espectador familiarizado con el arte contemporáneo próximas a algunas estéticas del siglo XX como el arte povera o el arte minimalista. Si fuera así, se rompería el tabú señalado por Sontag (\# II) que considera extremadamente desafortunado que, en sucesos de tipo catastrófico, la función poética se haga valer por encima de la comunicativa. Argumentaremos (\# 5) que la capacidad simbólica del arte puede evitar tal interpretación. 
Resulta imposible no abordar el tema de las fotografías de cadáveres. En internet tropezamos con alguna imagen que rompe con la interdicción señalada por Sontag que prohíbe la presentación al descubierto del rostro del muerto (Sontag, 2010: 63). Los servicios de seguridad tomaron precauciones para evitar el acceso visual a los lugares donde había cadáveres todavía sin embolsar.

Pero, sin embargo, resultan demoledoras las fotos, en las que algún cadáver yace en el suelo tapado apenas con una manta. O, más aún, otras en las que se ven desnudas las piernas de fallecidos. E incluso imágenes en las que los muertos han sido introducidos completamente en bolsas (Imagen 5) ${ }^{7}$.

Del mismo modo, es inevitable hacer referencia a las denominadas "fotografías censuradas" y a cierta polémica existente en internet respecto a las mismas. Los relatos de los supervivientes y de los testigos inmediatos de las explosiones narran lo que las máquinas fotográficas pudieron registrar pero se considera intolerable mostrar. No sólo los cristales rotos, el mobiliario destrozado o la sangre, sino los fragmentos de cuerpos humanos esparcidos por doquier. Existen fotos de las mismas e incluso han llegado a circular por Internet. A quienes escriben este texto, les produjo repugnancia la insistencia con la que algunas personas solicitaban reiteradamente que se les hiciera llegar las imágenes a su correo electrónico personal, ya fuera por razones personales sin definir, por intereses académicos, o por simple y confesado morbo. Otras personas contaban que las habían visto, que eran espeluznantes, y que las habían borrado de sus archivos. Otras, en fin, apelaban a la dignidad de las víctimas y sus familiares exigiendo que no se difundieran.

¿Por qué se desean ver tales imágenes? En su libro Ante el dolor de los demás, publicado originariamente en 2003, Sontag comenta con sarcasmo de qué manera "la apetencia por las imágenes que muestran cuerpos dolientes es casi tan viva como el deseo por las que muestran cuerpos desnudos” (Sontag, 2010: 41). Cita también cómo Platón ejemplifica en una ocasión la lucha entre las potencias del alma, entre lo racional y lo irracional, en relación a la tentación de mirar cadáveres. Por otra parte, consideramos relevante recordar que Walter Benjamin, hacía 1931, distinguía las imágenes ópticas que mantienen la distancia psíquica, y las imágenes hápticas o táctiles de las que el espectador se intenta apropiar del contenido psíquica o físicamente. En relación a esta línea de pensamiento, resulta obvio que la facilidad de las técnicas actuales de realizar fotografías con muy diversos tipos de dispositivos así como de almacenarlas y difundirlas por internet no hace sino confirmar en nuestros días el incremento del impulso "háptico" o "táctil” de "adueñarse de los objetos en la más próxima de las cercanías, en la imagen, más bien en la copia, en la reproducción” (Benjamin, 1973: 25). Nos encontramos, pues, ante un hecho civilizatorio de incuestionable carácter macabro.

Desde un punto de vista moral, lo que está kantianamente en juego es la dignidad de las personas. En este sentido, quien considere la preservación de la dignidad

${ }^{7}$ Incluimos esta fotografía pese a la turbación moral que nos produce hacerlo. 
como un derecho humano universal puede suscribir la radical respuesta proclamada por Manjón respecto a la utilización de imágenes del 11-M: "por encima del derecho a la información, está el derecho de los ausentes a preservar su intimidad" (AAT, 2005: 50). En su discurso, Manjón se escandalizaba ante la ineficacia de un Estado al que los ciudadanos demandan el ejercicio de la racionalización que, en parte, lo justifica. Por ello, exigía que se depuraran "responsabilidades respecto a la filtración y posible venta de las imágenes de los atentados” (AAT, 2005: 53). Pero, quizá con aún mayor penetración, se preguntaba "¿cómo pudieron filtrarse imágenes sometidas a secreto de sumario?” (ídem). Pues tal filtración pone de manifiesto la quiebra de una de las razones que avalan el Estado de Derecho: a saber, el empeño por defender la seguridad de las personas por lo que concierne a la vida, bienes, garantías jurídicas o a su propia imagen.

Por el contrario, frente a la utilización de las víctimas, una de las frases que más repercusión tuvo al referirse a los atentados sostenía que en aquel tren, en aquellos trenes, "íbamos todos”. Se trata, desde luego, de una apelación a la solidaridad, y en ese sentido una fórmula de consuelo. Pero comporta también implícitamente la idea de que el asesinato y la vejación de la dignidad de las víctimas del atentado, así como los fallos advertidos en los mecanismos de seguridad del Estado, afectan a todos los ciudadanos. A este respecto, las cámaras fotográficas captaron impactantes testimonios como el sencillo montaje en el que alguien había colocado un espejo donde el viandante podía verse reflejado. La apelación a la toma de conciencia se reflejaba en el rótulo: “Mírate. ¿Podías haber sido tú?” (Imagen 6). ${ }^{8}$

De esta forma, las fotografías del 11-M, junto con otros documentos, remiten también al fenómeno teorizado especialmente por Ulrich Beck y por Anthony Giddens conocido como la sociedad del riesgo, uno de cuyos fenómenos más alarmantes lo constituye el terrorismo internacional, que afecta, como escribe Giddens, "a todos, o al menos a gran número de personas en el planeta” (Giddens, 1999: 120).

${ }^{8}$ Este montaje que, obviamente, no pretende ser una “obra de arte”, tiene, sin embargo, un carácter próximo al arte conceptual. Las faltas de ortografía del texto hacen suponer que quién lo ha realizado probablemente no tiene grandes conocimientos culturales, lo cual no obsta para que, en su carácter improvisado, la plasmación de la idea sea contundente y artísticamente valiosa. 


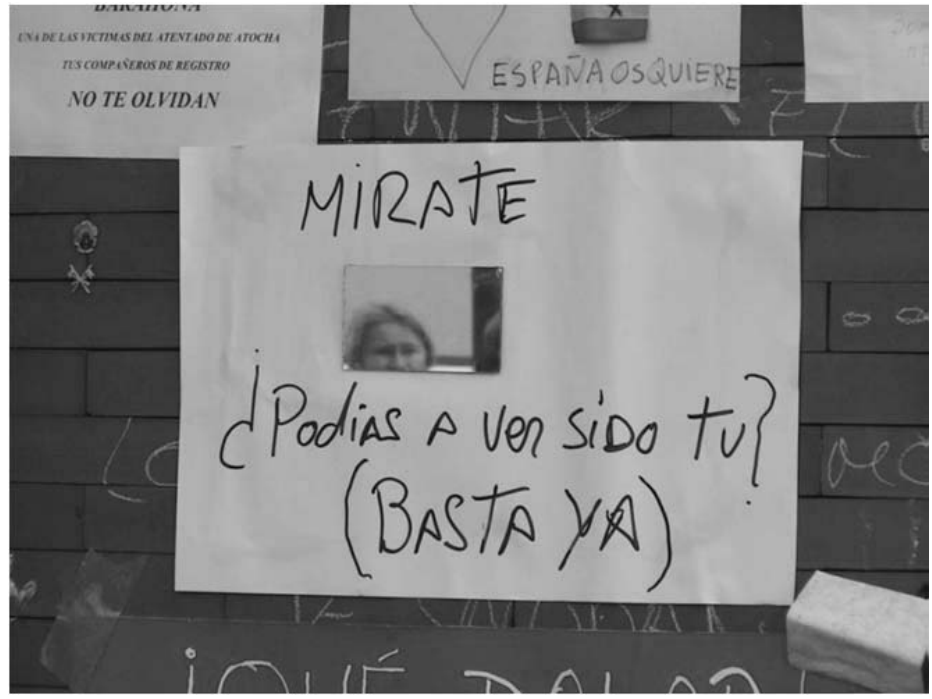

Imagen 6

\section{Fotografías de ofrendas. El impulso comunitario}

En los días que siguieron al 11-M, y fundamentalmente en las estaciones ferroviarias donde tuvieron lugar los atentados, surgieron lo que la Antropología reciente ha denominado "altares espontáneos", los cuales incluyen muestras de homenaje o solidaridad con víctimas de algún tipo de hecho. Como han analizado varios investigadores del CSIC, los altares del 11-M incorporan patrones de duelo ante muertes sentidas colectivamente como traumáticas (Sánchez Carretero, 2011b: 15). En el caso del 11-M, estaban integrados por velas rojas, flores, mensajes escritos, fotografías, iconografía religiosa, objetos diversos entre los que eran abundantes prendas de ropa o juguetes, y fotografías (de éstas se recogieron 2482).

Como hemos dicho (\#1), una estación de tren es un espacio prototípico de la modernidad en cuanto encarna la complejidad de la racionalización de las sociedades modernas y porque evidencia cómo las ciudades son los escenarios de una cultura en la que prepondera lo objetivo sobre lo subjetivo y personal (Simmel, 1986: 259-260). Lugares donde el trasiego de personas propicia que los contactos entre desconocidos sean superficiales y esporádicos. Puntos de encuentro efímeros ya sea de recepción o despedida de personas. Donde el entrecruzamiento y flujo de individuos y mercancías crea la impresión de un dinamismo permanente característico de lo que Zygmunt Bauman ha denominado sociedad líquida, en la que todo lo que nace lo hace "para morir inmediatamente" (Bauman, 2007: 23). Inevitablemente, los “altares espontáneos” estaban destinados a desaparecer ya que así lo requería 
la recuperación de la rutina de las estaciones incluyendo la limpieza y salubridad de sus recintos. Como indica la denominación utilizada, lo que surgió en ellos, frente a la asepsia funcional, fueron muestras de solidaridad personal que se afirmaban como ofrendas, con frecuencia estremecedoras, a los desaparecidos; como un vínculo de los vivos con los muertos, a modo de oración religiosa o profana.

Las fotografías mediante las que el Archivo del duelo dejaba constancia de los homenajes mencionados tomaban como modelo la estética del bodegón fotográfico. Al contrario de las fotos que se tomaron durante las fases de auxilio (\# II), lo que se mostraba ahora no era precipitación o movimiento, sino quietud y recogimiento. Altares que se iban componiendo de modo espontáneo a medida que los oferentes añadían sus contribuciones ${ }^{9}$.

Por otra parte, en las fotografías tomadas de los altares son claros tres rasgos. En primer lugar, (a) el intento de captar la mayor información posible de los objetos. Como consecuencia, las tomas son frecuentemente frontales intentando con ello especialmente por lo que respecta a los mensajes escritos- facilitar la mejor visualización de las ofrendas, (Imagen 7) incluyendo la lectura de las mismas cuando hay mensajes escritos. Se incluyen frecuentemente textos de gran emotividad como en el regalo -destinado a la celebración del Día del padre en el cercano 19 de marzoque una niña hace a su progenitor de una corbata pintada de colorines con la leyenda "te quiero papá" y la respuesta también escrita del padre: "Gracias hija, tú me tienes a mí. Otros niños los han perdido. Tú y yo rezaremos por ellos”.

En segundo lugar, (b), y de modo similar en este caso a las fotos de auxilio, el fotógrafo actúa con la máxima discreción posible. Los sujetos fotografiados, se hallan colocando velas (Imagen 8), a menudo en familia, rezan, miran el río de velas formado o leen mensajes. En tercer lugar (c), y como consecuencia ante todo de la primera característica existe un claro predominio de la función comunicativa sobre la estética.

${ }^{9}$ De esa forma, como ha señalado Paloma Díaz-Mas, podía tener lugar una autoría colectiva como resultado de la intervención de distintas personas a partir de un primer mensaje, ya fuera mediante añadidos (imágenes, escritos, inscripciones...) o alteraciones de la disposición. (Díaz-Mas, 2011: 91). 


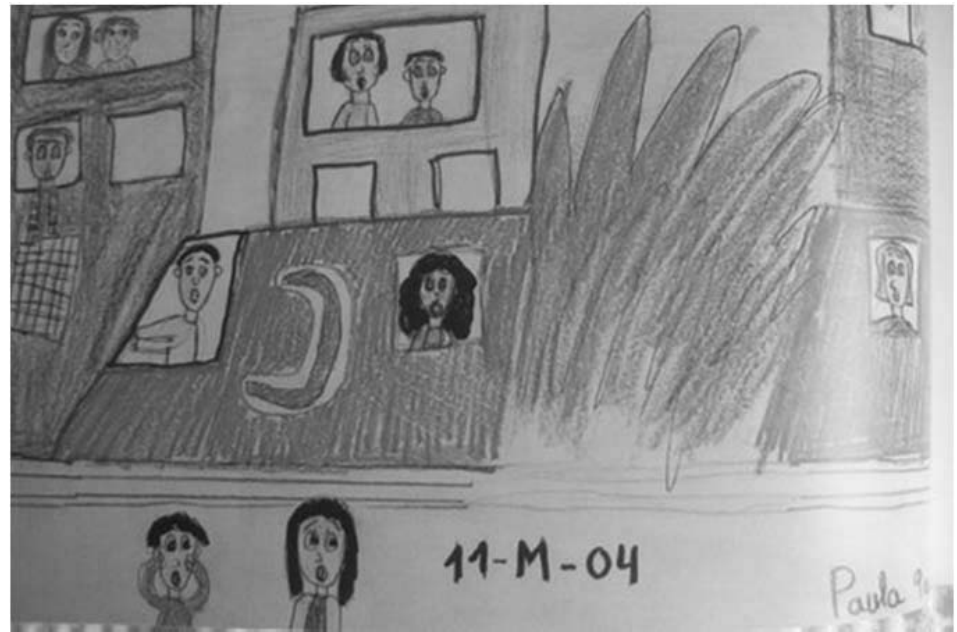

Imagen 7

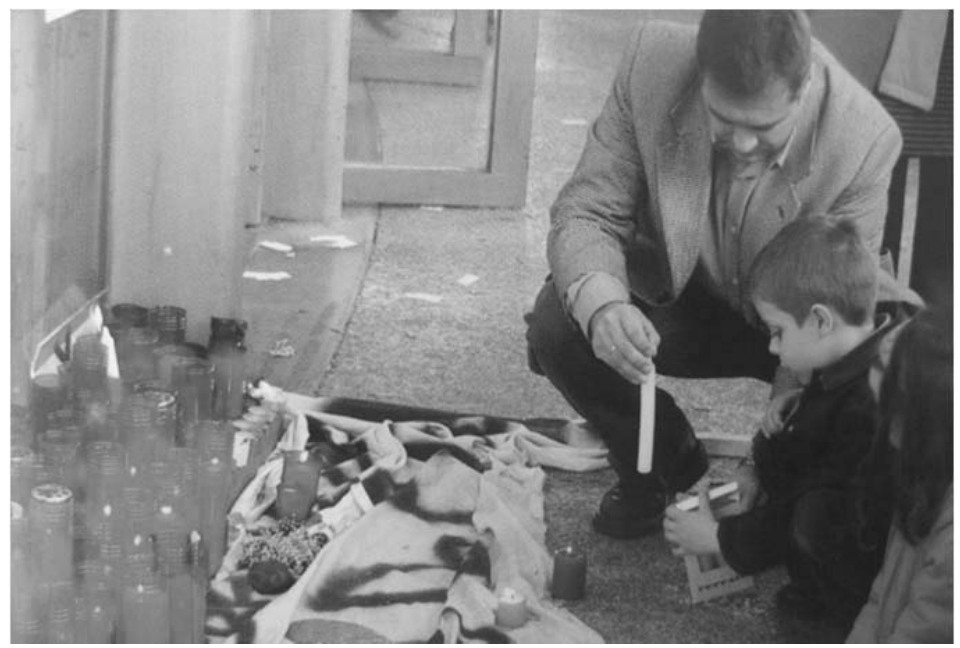

Imagen 8

Sin embargo, hay algunas fotos en las que el cuidado formal, estético, de la imagen o de lo fotografiado, logra con especial éxito el propósito, sin duda, común a todas las ofrendas: servir como símbolo de la comunicación con los afectados. Pues, en efecto, como señala José García Leal, la función esencial del símbolo es "la de dar cierta presencia a lo ausente” (García Leal, 2002: 83). Lo ausente, en este caso, son tanto los afectados, especialmente los que murieron, como el intangible vínculo que guarda la ciudadanía o los familiares con ellos. Pues bien, entre todos los medios 
de expresión, y tal como escribía en 1976 Cartier-Bresson, "la fotografía es el único que fija el instante preciso" (Cartier-Bresson, 2003: 19). Y continuaba afirmando que esta actividad puede intentar "captar el hecho verdadero con relación a la realidad profunda" (Cartier-Bresson, 2003: 20); merced, añadimos, a su capacidad sintética de remontarse de lo concreto a lo universal.

Incluso, en algunas escasas ocasiones, las ofrendas se hallan próximas, conscientemente o no, a corrientes del arte contemporáneo. Los antropólogos del Archivo del duelo, por ejemplo, han captado con sus fotografías una convincente instalación de 200 esquelas, cada una de las cuales incluye una sencilla cruz y el mismo texto: "Falleció en atentado terrorista. Descanse en paz. Todos nos unimos al dolor de su familia y amigos. Rogamos una oración por su alma"10. (Imagen 9).

De esta forma, vamos observando cómo es probable que la fotografía de objetos, menos capaz de ser considerada como una posible intromisión en la imagen personal, facilite que la función comunicativa no aparezca en conflicto con la función estética, considerada como inoportuna en las fotografías de auxilio (\# 1).

Por último, características de estas ofrendas como la agrupación en espacios públicos, su proclividad a ser resultado de la colaboración colectiva o la frecuente expresión de mensajes de solidaridad y apoyo incluso a quienes no se ha conocido no son ajenas al surgimiento o recuperación, aunque sea provisional en el tiempo, de un rasgo propio de las agrupaciones humanas que algunos autores clásicos de la sociología -Max Weber, Ferdinand Tönnies, Georg Simmel...- denominaron "comunitarias” (Gemeinschaft) en contraposición a la vinculación asociacional (Gessellschaft) propia de las grandes ciudades. A saber, el sentimiento de pertenencia a un todo. Algo que ilustra de forma especialmente clara el lema "todos íbamos en ese tren" ${ }^{\text {, }}$, frecuentemente repetido en las ofrendas y en otros mensajes.

${ }^{10}$ Este montaje-ofrenda se halla próximo a la corriente artística del arte conceptual, determinante en el siglo XX con Marcel Duchamp como una de sus referencias básicas.

${ }^{11}$ Aunque con un sentido distinto, de denuncia política, la recuperación del nosotros comunitario es clara también en otro lema frecuente: "Vuestras guerras, nuestros muertos". 


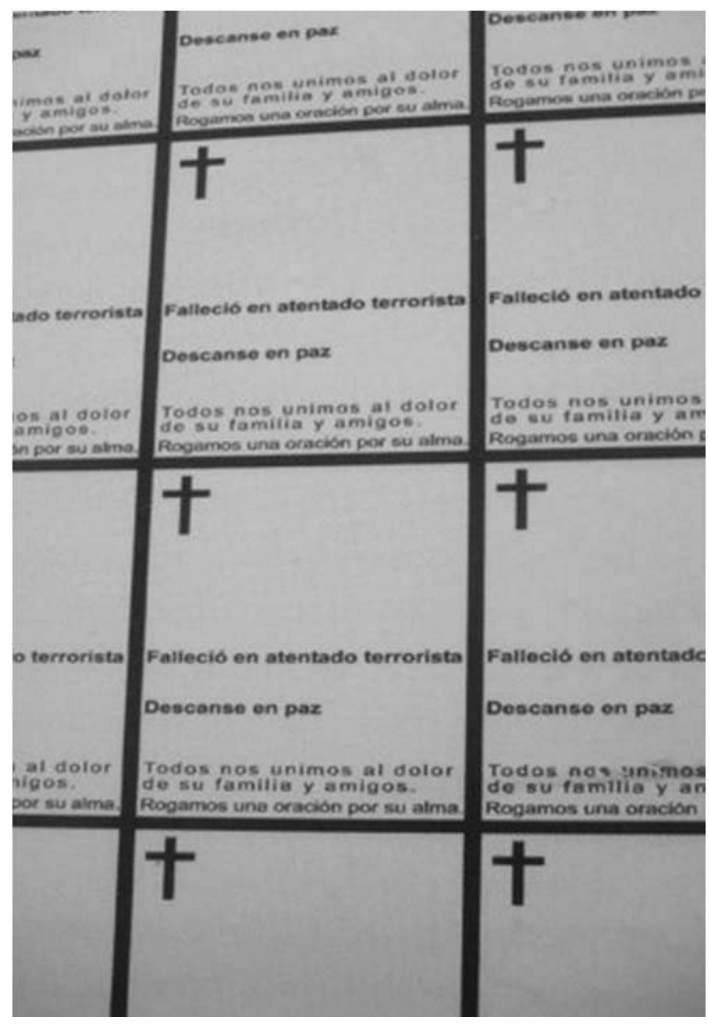

Imagen 9

\section{Fotografías de ofrendas. El impulso personal}

Tal sentimiento se refuerza, como vamos viendo, a través de acciones, como los altares espontáneos que van modificándose, y creciendo, con las aportaciones que realizan otras personas. Una imagen poderosa y sintética de ello la constituía el recurso al símbolo surgido en 1996, también en Madrid, tras el asesinato en su despacho de la Universidad Autónoma de Madrid del catedrático de Historia del Derecho Constitucional, Francisco Tomás y Valiente ${ }^{12}$. Nos referimos a las manos blancas. En sus diversos modos (como pintura en las manos, dibujos, grabados...) expresan el sentimiento ciudadano de quienes, frente a los asesinos -cuyas manos están manchadas de sangre inocente- recurren únicamente a procedimientos pacífi-

${ }^{12}$ Asesinado por ETA. 
cos y racionales para defender sus puntos de vista. Desde 1996 ha sido un símbolo frecuente para expresar el rechazo a la violencia. Pues bien, las manos blancas fueron, tal como era previsible esperar, un símbolo contra el atentado del 11-M, tanto a modo de ofrendas como en concentraciones públicas. Expresaban la demanda de paz y racionalidad por parte de la ciudadanía. Entre las imágenes de las ofrendas captadas fotográficamente resaltaremos una de ellas, a la par sencilla y vigorosa, (Imagen 10) que expresa muy claramente la contribución al sentimiento comunitario colectivo ${ }^{13}$. Se trata de un detalle de la escultura de Luis Arencibia como monumento homenaje a las víctimas de los atentados en Leganés; localidad donde el 3 de abril de 2011 murió un miembro de las fuerzas de seguridad a causa de la explosión en la que se suicidaron siete yihadistas implicados directamente en los atentados ${ }^{14}$. De esta forma, se construye un nosotros que quedó plasmado durante el tiempo que permanecieron instalados los altares; aunque luego el ritmo de la ciudad metropolitana -un tipo de asociación (Gessellschaft) vinculada al cálculo- lo debilite a medida que cada cual vuelve a sus quehaceres habituales.

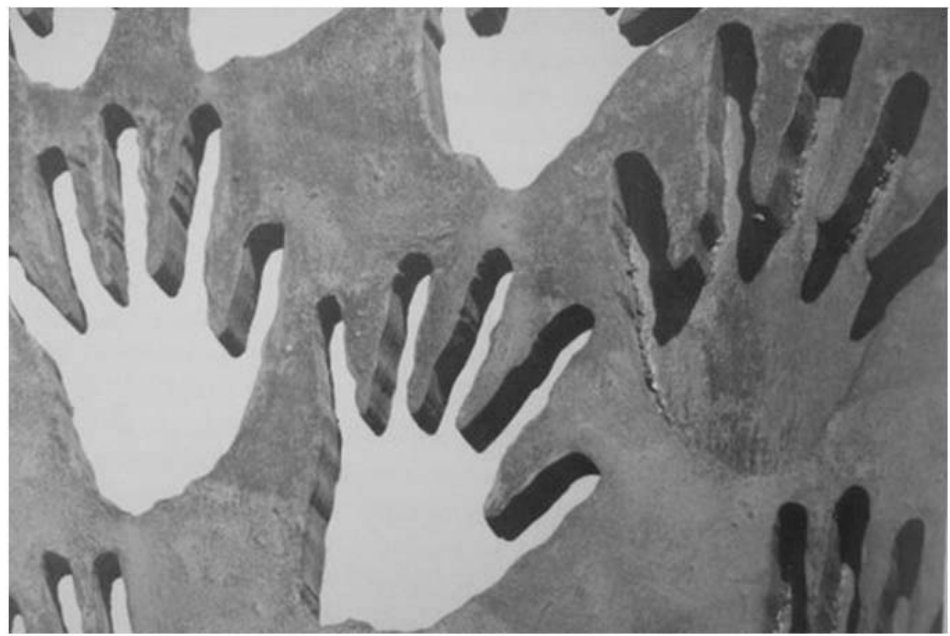

Imagen 10

${ }^{13}$ También se recurrió a este símbolo cuando se sustituyeron los altares espontáneos por el virtual “espacio de palabras” instalado en la estación de Atocha (\# IX). También allí los viandantes podían sumar la huella de sus manos.

${ }^{14}$ El dramatismo y la tragedia de la muerte del subinspector Francisco Javier Torrenteras se vio acrecentada por la profanación, el 19 de abril de 2004, de su cadáver. Este último hecho, sin embargo, no fue conocido suficientemente por la ciudadanía y, como ha señalado el profesor Reinares, no suscitó la reacción de repulsa, la investigación del caso y el homenaje al servidor público que hubiera sido necesaria (Reinares, 2012). 
Ahora bien, aunque el sentimiento comunitario sea muy relevante para mostrar y construir el sentimiento de ciudadanía -y probablemente también como recurso psicológico para intentar superar el trauma de la muerte de personas allegadas-, los familiares y amigos quisieron individualizar a las víctimas. Se trata de una demanda cívica en la medida en que se considera que es ante todo la persona individual la que constituye el sujeto de la vida ciudadana. La misma que ha perdido la vida o ha resultado herida como consecuencia de un acto asesino indiscriminado, es decir, indiferente a la individualidad de los seres humanos ${ }^{15}$. De este modo, exigir el reconocimiento de la identidad individual de todas y cada una de las víctimas es expresión de una mentalidad en la que las "ideas de elección personal, libertad e individualidad están bien asentadas” (Sánchez-Carretero, 2011b: 18), tal como ha comentado Tony Walter y cita Sánchez-Carretero.

Este deseo de individualización se sintetiza en un aspecto singular, e incluso sorprendente, como es el de hacer público lo privado a través de los dos aspectos que singularizan, que dotan de individualidad reconocible públicamente, a una persona: su nombre y su rostro. De este modo, el reconocimiento de la individualidad de las personas adquiría el carácter de demanda cívica. Esto ocurrió al menos en tres aspectos. En primer lugar, y como ha escrito Díaz-Mas, en los textos escritos de las ofrendas se recurría muy a menudo a referencias a personas concretas "como forma de inmortalizar y perpetuar el recuerdo individualizado de las víctimas" (Díaz-Mas, 2011: 89). En segundo lugar, nos detendremos en ello en seguida, y como también ha señalado Carmen Ortiz (Ortiz, 2011: 53-60), en la presentación de fotografías ${ }^{16}$. En tercer lugar, de forma más conceptual, el discurso de la Asociación 11-M. Afectados del Terrorismo demandaba el reconocimiento de las víctimas en su individualidad con las consecuencias simbólicas, económicas, sociales y jurídicas que fueran pertinentes tanto en su memoria como en la dignidad del trato a los familiares.

De esta forma, se pasaba del consuelo que ofrece el sentirse y ser reconocido como miembro de una comunidad (\# 4) a la exigencia de considerar a las víctimas como individuos concretos. Como leía, emocionada y contundentemente, Pilar Manjón, frente a la decepción que habían sentido los miembros de la AAT ante los trabajos de la comisión de investigación parlamentaria que se ocupó de los atentados, su discurso en el Congreso de los Diputados pretendía presentarlos ante los

${ }^{15}$ Refugiado en la concepción de que los supuestos derechos de grupos colectivos, como razas, pueblos o religiones son anteriores a los derechos de las personas individuales.

${ }^{16}$ En el célebre texto citado anteriormente, Benjamin señalaba que con la reproducción técnica el valor exhibitivo de la imagen iba reprimiendo el valor cultual. Sin embargo, éste guarda un lugar importante en "el rostro humano (...) El valor cultual de la imagen tiene su último refugio en el culto al recuerdo de los seres queridos, lejanos o desaparecidos” (Benjamin, 1973: 31). La exigencia de trato respetuoso de la imagen por parte de los familiares de las víctimas recupera tal valor cultual de modo completamente distinto al posible uso de esas mismas imágenes con interés de mero consumo o incluso de uso morboso. 
diputados vivos "como lo están en nuestros corazones, en nuestra memoria y como punto de referencia de nuestra vida cotidiana. Señorías, para nosotros tienen nombre y rostro (Javi, Pilar, Daniel, Eva Belén, Susana, Emilian, Carlos, Óscar, Rodrigo, Rodolfo, José Luis, Sonia, Abel...) y cada uno de ellos es imprescindible e irrepetible, pertenecen a nuestras vidas, a la de sus familias, sus amigos, sus compañeros de trabajo, de clase, eran vecinos... Los necesitábamos” (AAT, 2005: 9-10).

Las fotografías recogidas por el Archivo del duelo muestran la concepción a la que nos hemos referido. Hacen presentes, con datos personales -nombres, fechas de nacimiento, rostros, objetos usados por los difuntos...- a los ausentes, a los asesinados. Muestran, por ejemplo, el nombre y fechas de nacimiento de una persona enmarcadas dentro de un corazón. La fotografía, al registrar un instante del tiempo, hace presente y aporta la concreción irrefutable de su hallarse delante del objetivo. Fija un momento temporal y lo convierte, como dijo Ortega y Gasset en un texto de 1914 refiriéndose a la narración, en un 'fue'. "Y el fue es la forma esquemática que deja en el presente lo que está ausente, el ser de lo que ya no es” (Ortega y Gasset, 2004. Vol I: 672). Lo fotografiado también es un 'fue'. Una fotografía es la presencia de una ausencia. De ahí, su capacidad de movilizar el recuerdo, y las alegrías o nostalgias consiguientes. Como no podía ser de otra manera ante los asesinatos del 11-M, las fotografías de los asesinados adquieren un dramatismo excepcional. De modo distinto a las tomadas durante las tareas de auxilio, las que los familiares incorporaron a las ofrendas muestran a los fallecidos en su vida cotidiana, recurriendo al patrón usual de la pose frontal, y con ello, brindando gran cantidad de información (Imagen 11) de su vida cotidiana. Mirándonos frontalmente con la vida por delante, sin poder sospechar su terrible final.

A veces, las fotografías que aluden a rasgos personales muestran mensajes cuyos destinatarios son los fallecidos. De forma singularmente dramática, en memoria de niños asesinados, como Patricia, que no podrían celebrar con sus padres el 19 de marzo la festividad de San José. En otras ocasiones, la fotografía refleja el acumularse de mensajes dirigidos en primera persona a un difunto concreto; es el caso de los que dirigen sus compañeros de estudios a Iris ${ }^{17}$.

Se trata, pues, de mensajes personales que expresan no sólo el sentimiento de pérdida y de dolor, sino también la convicción de los allegados que han sobrevivido de considerarse, como se lee en el discurso leído por Manjón, representantes de su "derecho al honor y a la propia imagen" (AAT, 2005: 53). De nuevo, una demanda cívica frente a la agresión que supone que esa representación de los difuntos fuera utilizada de forma partidista o manipuladora por fuerzas políticas, medios de comunicación o instituciones, públicas o privadas. A ese respecto, entre la lista de

${ }^{17}$ Carmen Ortiz ha señalado el aspecto performativo tanto de las ofrendas y de los "altares espontáneos” como de las imágenes de los fallecidos, las cuales se incorporan a la memoria de los vivos, individual y socialmente, como algo propio (Ortiz, 2013: 57-71). 
exigencias del discurso de la Asociación 11-M. Víctimas del terrorismo se incluían dos específicas:

"5. Respeto a la voluntad de las familias para el uso de los nombres y las imágenes de los fallecidos y supervivientes en todos los actos públicos y privados que se realicen en su memoria” (AAT, 2005: 60).

"8. Exigimos el respeto del derecho a la intimidad, así como la investigación de las responsabilidades derivadas del filtrado de los datos personales, direcciones y teléfonos de los afectados a terceras instituciones para su uso particular" (AAT, 2005: 61).

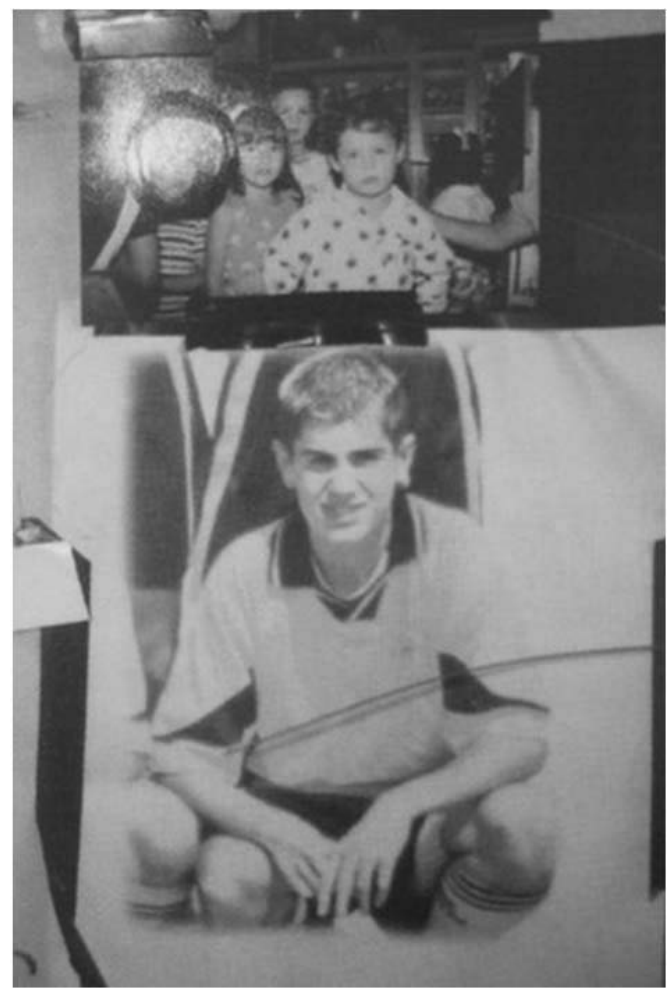

Imagen 11

\section{Fotografías de concentraciones}

¿Es el sentimiento comunitario una ilusión? Sánchez-Carretero nos informa de que "los memoriales desde las bases, surgen cuando las muertes son sentidas como propias por lo que se denomina una 'comunidad imaginada'” (Sánchez-Carretero, 2011b: 16). ¿Se trata de una comunidad ilusoria? Sontag advierte, por su parte, que "la compasión es una emoción inestable” (Sontag, 2010: 87). Teniendo en cuenta el 
sentimiento comunitario mencionado (\# V) afirma que "no debería suponerse un 'nosotros' cuando el tema es la mirada al dolor de los demás” (Sontag, 2010: 14).

Sin embargo, la difusión de las noticias de la masacre suscitó de modo inmediato y espontáneo reacciones de solidaridad. Los servicios públicos - policía, bomberos, servicios sanitarios...-, los medios de comunicación, los profesionales del transporte... aportaron su trabajo. La población acudió de forma masiva a donar sangre hasta el extremo de que fue necesario recomendar que, dada la caducidad de este elemento, la donación se demorara a fechas posteriores.

Como ha escrito Fernando Vallespín, "no sólo la 'subjetividad' (de subiectare, sujetar) nos aferra a la vida, también 'somos' porque formamos parte de una colectividad; en cada yo se conjuga también un 'nosotros'” (Vallespín, 2005: 7). Referido a grupos concretos de diverso orden: familiares, laborales, ciudadanos... En relación a este punto, resulta de singular interés constatar que el civismo de la ciudadanía no dejó lugar a brotes xenófobos o racistas contra extranjeros o inmigrantes, cualquiera que fuera su nacionalidad; ni siquiera una vez conocido que los atentados estaban vinculados a la red Al Qaeda. Tampoco contra personas de distintas religiones distintas a la católica, representada iconográficamente en las ofrendas (\# 4) de forma especialmente abundante. En el cortometraje Españoles por vía de sangre (Barbadillo, 2004) se afirma que el 70\% de los inmigrantes muertos no tenía la documentación en regla; lo cual constituye un dato relevante sobre una sociedad cuyo funcionamiento cotidiano parece escapar parcialmente a la racionalización burocrática -y, por tanto, también económica y jurídica.

El mismo día, y en los días posteriores, se produjeron concentraciones de repulsa en los centros de estudio o de trabajo. Los fotógrafos han captado el impulso solidario procurando mostrar la gran agrupación de personas. En algunos casos, los fotografiados se hallan frontalmente frente a las cámaras, en otros han sido captados de espaldas (Imagen 12).

Frecuentemente, los fotógrafos han considerado significativo el gesto de levantar las manos, en alusión al ya comentado (\# 5) gesto consolidado de las manos blancas; son frecuentes los lazos negros como expresión del duelo, y la presencia de la palabra "paz” (Sánchez-Carretero, 2011b: 15).

Un dato curioso y relevante es que en las concentraciones callejeras no aparecen palabras como "amor” o "solidaridad” que sí abundan entre las ofrendas (SánchezCarretero, 2011b: 15). Quizá porque en el caso de las ofrendas nos hallamos ante expresiones de duelo en un espacio en el que, de forma implícita, se aplica como patrón de conducta coherente el silencio y el recogimiento. Por el contrario, en las expresiones que tienen lugar en la calle -con la excepción de los rituales "minutos de silencio"- quienes se concentran o se manifiestan quieren hacer oír su voz. A las 12 horas del día 12 de marzo se convocan concentraciones contra el atentado terrorista. En seguida, el recogimiento cede el paso a la demanda cívica. Y el civismo adquiere contenido político. 


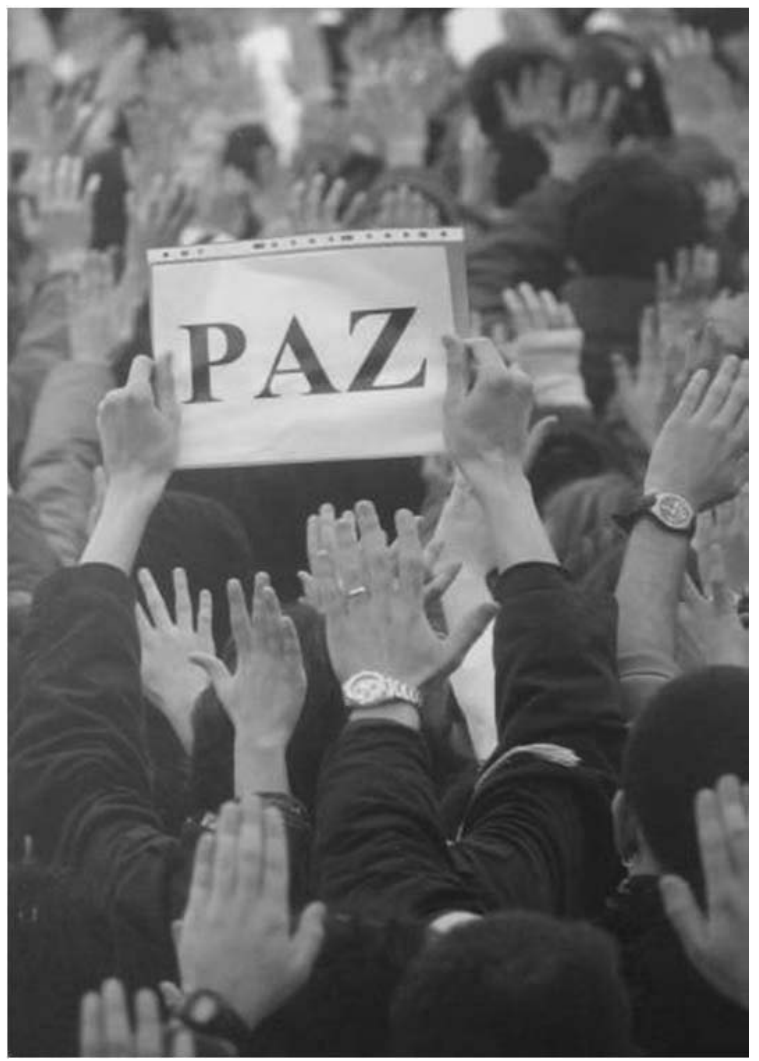

Imagen 12

\section{Fotografías de manifestaciones}

Una de las reacciones inmediatas de la ciudadanía fue interrogarse por la causa de los atentados. Esta pregunta aparece también en los mensajes hallados entre las ofrendas: ¿por qué? En este caso, se expresa una reacción de sorpresa, de estupor, de incomprensión moral ante la salvajada. Se intenta averiguar las razones que llevan a unos seres humanos a asesinar a otros de forma indiscriminada. Manifiesta la incredulidad moral ante el hecho terrorista.

Pero, la pregunta adquiere súbitamente otros tres sentidos: ¿quiénes son los autores de la masacre?, ¿por qué se ha cometido?, ¿hay responsables políticos de la misma en la vida política española? En un primer momento, el gobierno presidido por José María Aznar, del Partido Popular (PP), asegura de forma tajante que la banda terrorista ETA es la responsable de los atentados. Continúa, como es sabido, 
manteniendo esa posición pese a que pronto surgen indicios creíbles de que la atribución debe trasladarse a algún grupo terrorista islámico.

A las 14 horas del día 12 de marzo, el Ministerio del Interior da una serie de datos que parecen encaminar las sospechas hacia la organización Al Qaeda. Surge la desconfianza acerca de la posible ocultación y manipulación de datos con fines partidistas por parte del Gobierno. Todo ello sucede cuando las elecciones generales están fijadas para el domingo 14 de marzo, siendo el día anterior jornada de reflexión.

El 12 de marzo es en Madrid una jornada lluviosa. Se convoca una manifestación entre la plaza de Colón y la estación de Atocha. Se calcula que en Madrid se manifestaron dos millones trescientas mil personas; unos once millones en toda España. Es el día anterior a la jornada de reflexión ante las inmediatas elecciones. Pronto resulta evidente que, ante los atentados, buena parte de la ciudadanía no está dispuesta a considerar que la política se restringa a la consulta electoral y a los espacios institucionales. Las calles se convierten en espacio de las demandas de control cívico del comportamiento de los dirigentes políticos. Las voces de los manifestantes exigen saber la verdad de lo que ha ocurrido. Entre las proclamas coreadas se hallan “¿quién ha sido?” y “iqueremos la verdad antes de votar!”. Las fotografías de la manifestación de Madrid presentan varias características. (a) Se realizan tomas panorámicas en las que se capta la multitud bajo los paraguas. (b) Se muestran fotos de miembros de la familia real y de líderes políticos del PP y del PSOE en la cabecera de la manifestación como expresión de la unidad de las autoridades simbólicas y políticas del país. (c) Son frecuentes los manifestantes que alzan sus brazos mostrando las palmas de sus manos.

Manuel Castells ha incidido en la importancia que tiene en los movimientos del siglo XXI, la comunicación a través de Internet. "La interactividad permite a los ciudadanos solicitar información, expresar su opinión y pedir una respuesta personalizada a sus representantes. En lugar de que el Gobierno vigile a las personas, la gente podría vigilar a su Gobierno, algo a lo que deberían tener derecho, ya que en teoría el poder reside en el pueblo" (Castells, 2003: 200). Pues bien, esta actitud es la que se manifiesta en forma de durheimiana corriente social y probablemente de forma espontánea, es decir, independiente de las estructuras convencionales de los partidos políticos. En una vertiginosa jornada en la que los correos electrónicos y los mensajes enviados por teléfono móvil cumplen un papel decisivo, se producen convocatorias de concentraciones ante la sede del PP en Madrid, en la calle Géno$\mathrm{va}^{18}$. De nuevo, las manos desnudas, pero esta vez con frases inquisitivas escritas en ellas: “la verdad, ya”, “¿quién ha sido?” (Imagen 13). Aunque sería exagerado decir que ahora sí que hay pose, los manifestantes quieren que se vean los escritos que aparecen en sus manos o en sus camisetas. Se colocan con frecuencia frontalmente ante las cámaras fotográficas para que se registre su gesto y su demanda.

${ }^{18}$ Manuel Campo Vidal (2004) hace un análisis de este aspecto. 
Quieren saber la verdad. Exigen transparencia como un requisito fundamental del funcionamiento democrático.

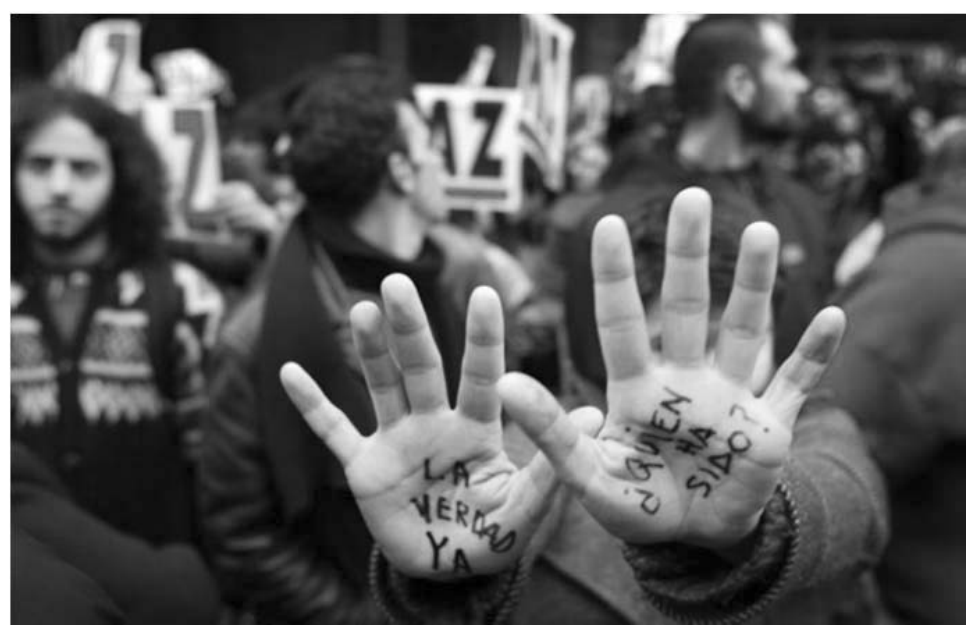

Imagen 13

Desde un punto de vista sociológico, la reacción ciudadana evidencia uno de los rasgos definitorios de la modernidad, la reflexividad. Tal como escribe Anthony Giddens: "la reflexión de la vida social moderna consiste en el hecho de que las prácticas sociales son examinadas constantemente y reformadas a la luz de nueva información sobre esas mismas prácticas” (Giddens, 1999: 46). No es disparatado pensar que los atentados influyeron decisivamente en el presumible cambio de orientación en el voto por parte de muchas personas que acabó dando la victoria al PSOE.

La manifestación en Madrid del 12 de marzo, incluidas las concentraciones ante la sede del PP, muestran la tensión entre dos factores clave ya mencionados de las sociedades contemporáneas: por una parte, la existencia de una sociedad con un alto componente de racionalización (\# I) entendida como la adecuación de los medios para alcanzar fines ya sean productivos, tecnológicos, sanitarios, jurídicos... Por eso, como ha escrito Vallespín, los atentados del 11-M "rompen la premisa fundamental sobre la que se sustenta la sociedad moderna: la existencia de un marco de convivencia en el que la seguridad se da por sobreentendida” (Vallespín, 2005: 8). Pero, por otra parte, la sociedad contemporánea es también la sociedad del riesgo (\# IV), en la que la seguridad presupuesta anteriormente se encuentra amenazada en sus cimientos por factores que afectan de forma indiscriminada a la población. El terrorismo internacional es, sin duda, uno de ellos. 
Como consecuencia lógica de una sociedad que concibe la seguridad como un factor fundamental al tiempo que es reflexiva en el sentido propuesto por Giddens, la pregunta por las causas de los atentados no se limita al terreno moral sino que adquiere carácter político tomando importancia decisiva la cuestión de la responsabilidad. No la de los terroristas, con ellos no se cuenta, ni se quiere otra cosa que el que sean identificados, juzgados y condenados por sus crímenes. Sino la de los responsables políticos españoles.

Poco más de un año antes, el 15 de febrero de 2003, en nuestro país se habían producido grandes manifestaciones contra la guerra en Irak en la que Estados Unidos, Gran Bretaña y España participaron como aliados. Se hizo popular, por entonces, la expresión "el trio de las Azores" para referirse a los presidentes de los tres países mencionados, Georg Bush, Anthony Blair y José María Aznar respectivamente, reunidos el 15 de marzo de 2003 en aquellas islas. La justificación de que el gobierno de Irak, presidido entonces por Sadam Hussein, poseía armas químicas las cuales supondrían un peligro contra los países occidentales -algo en lo que Aznar insistió- se demostraron más tarde falsas, y fueron consideradas ampliamente como una manipulación. Con estos antecedentes, buena parte de la población interpretó que los atentados del 11-M por parte de Al Qaeda eran consecuencia de una venganza de grupos terroristas islámicos contra la presencia española en Irak. Se sospechó que el Gobierno, para no perjudicar sus expectativas electorales, ocultaba información sobre la participación de Al Qaeda en el atentado; algo que parecía reforzado en su contumacia inicial en atribuir la masacre a ETA. Sin que sea posible hacer estimaciones precisas, parte de los ciudadanos empezaron a considerar que el Gobierno de Aznar tenía responsabilidad en los atentados del 11-M debido a dos circunstancias. En primer lugar, su apoyo a la invasión de Irak intentando manipular a la población pública española cuya contundente y masiva voz contra la guerra se había dejado oír en las manifestaciones. España habría sido conducida a una guerra injusta. En segundo lugar, el Gobierno de Aznar habría sido ineficaz por lo que concierne a la previsión de un posible atentado terrorista.

La documentación fotográfica del 11-M muestra claramente que la palabra probablemente más empleada en las manifestaciones del 12 de marzo, "paz", era eco, y se hallaba en continuidad, de expresiones similares usadas en las manifestaciones de 2003 contra la participación a la guerra de Irak. El "No a la guerra” y "Paz" de 2003, aparecían en las críticas e insultos al Gobierno de Aznar en 2004 acusado de nuevo, como en 2003, de manipulación. Esta cuestión ponía de manifiesto como trasunto el debate teórico sobre los conceptos de democracia directa y democracia representativa, así como las relaciones entre la democracia política a través de las instituciones estatales y la sociedad civil.

La foto más conocida en España del "trio de las Azores" en la que Bush apoyaba una mano en el hombro izquierdo de Aznar, fue vilipendiada como la concreción del servilismo y de la irresponsabilidad. No puede sorprender que entre los mensajes que los viandantes expusieron en las estaciones de la muerte, junto con las ofrendas figuraran insultos y acusaciones dirigidos al todavía presidente de gobierno. Una foto recogida por el Archivo del duelo (Imagen 14) es especialmente 
significativa. Se reproduce la foto del trío y se añade como pie “¡Malditos!”. Además, delante de la foto se colocan tres máscaras de papel o escayola en alusión a la mendacidad de los tres personajes, y a su responsabilidad en haber atraído sobre Madrid las iras de los terroristas.

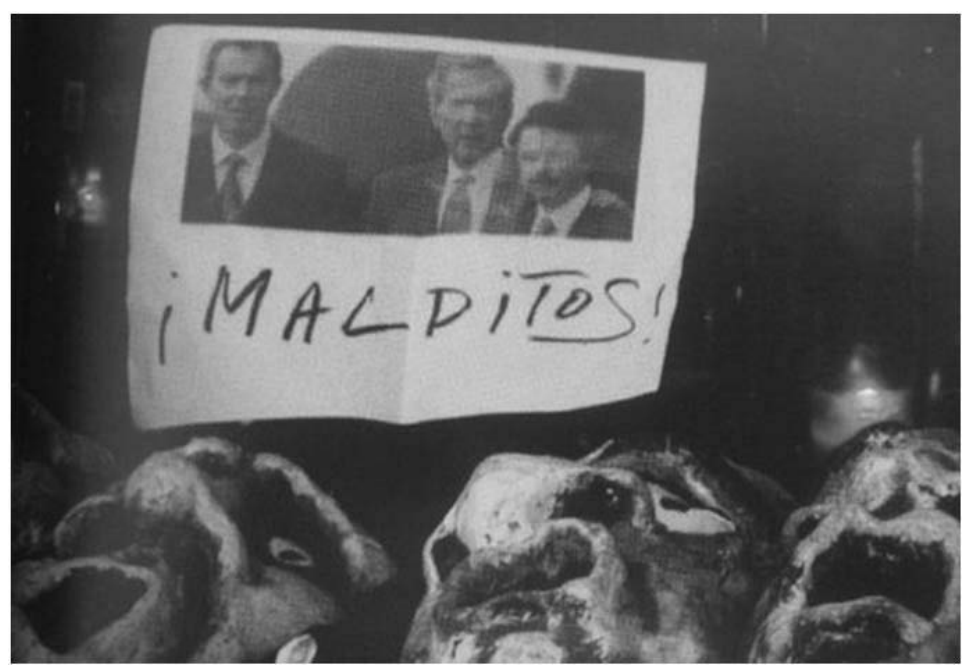

Imagen 14

De nuevo el discurso leído por Manjón constituye una ejemplar condena de la irresponsabilidad y clama por el incremento de la seguridad como forma de potenciar la racionalización de la sociedad y del sistema democrático. De forma contundente, a este respecto, el texto señalaba dos direcciones. (a) Exigir las "responsabilidades legales que, por la vía penal, deban imputarse a quienes, por error u omisión, no pusieron todos los medios a su alcance para evitar que esta tragedia nos azotara" (AAT, 2004: 24). Por ejemplo, falta de medios para investigar a presuntos terroristas, falta de investigación respecto a las tramas de tráfico de explosivos, o desidia ante los informes que avisaban de la inminencia de un ataque terrorista. (b). Condena de los "errores e imprevisiones" (AAT, 2004: 28) cometidos y, sobre todo, de la falta de asunción de los mismos por parte de los responsables políticos. Con un objetivo claro: "es imprescindible que algo tan execrable como esto no vuelva a ocurrir” (AAT, 2004: 27). Se trata, pues, de demandas respecto a lo sucedido en el execrable pasado del 11-M, pero también respecto al futuro de una sociedad que se quiere justa y racional.

Por eso, es significativo que en el mismo texto al que nos estamos refiriendo se aluda a una cuestión sociopolítica central, la del funcionamiento y legitimidad de las instituciones del Estado. En efecto, desde los primeros párrafos, Manjón reprochó a 
los parlamentarios el uso partidista de la Comisión nombrada para investigar los atentados, la cual, a su juicio, se habría desvirtuado "en el intento de usurpar la voz a los afectados, de deslegitimarlos, de someterlos a su propio juego político y de intentar encasillarlos en tal o cual opción” (AAT, 2004: 11). Como consecuencia, el Congreso de los Diputados no habría sido capaz de encarnar la Soberanía del Pueblo (AAT, 2004: 5) perdiendo con ello su sentido ${ }^{19}$.

Consiguientemente, es importante considerar que una de las cuestiones de fondo planteadas a raíz de los atentados del 11-M es la de la legitimidad de las instituciones democráticas, siendo de especial relevancia la percepción manifestada en el discurso leído por Manjón de la separación entre la sociedad civil y el Congreso de los Diputados, lo cual deslegitimaría a éste último. Ahora bien, del mismo modo que, como hemos recordado en este mismo apartado, los manifestantes querían conocer la verdad de los atentados antes de proceder a la votación, en el discurso de la AAT no se procedía a una descalificación de los mecanismos democráticos, sino que se exigía su mejor funcionamiento y racionalización, llegando incluso a proponer que hubiera una nueva Comisión capaz de proponer "reformas en el funcionamiento de las instancias del Estado" (AAT, 2004: 31).

De esta manera, advertimos que la respuesta ciudadana ante los atentados del 11M manifestaba la "indignación” (AAT, 2004: 30) ante la reducción de la política al mundo profesionalizado de los partidos políticos, así como su separación de valores éticos, morales, entre los que la transparencia debería ocupar un lugar decisivo ${ }^{20}$. Ahora bien, el discurso leído por Manjón -una vez rechazada la equiparación de política y partidismo- mostraba la esperanza de recuperar o ganar la relación entre instituciones democráticas y ciudadanía mediante la revitalización de la sociedad civil y de la participación ciudadana. Por eso, cuando Manjón leía que, “fuera de esta casa [la del Congreso de los Diputados] aún queda mucho aire fresco y mucha luz bajo el cielo” (AAT, 2004: 18) no estaba desdeñando la existencia de las instituciones democráticas, sino que estaba avistando la posibilidad de reanimarlas mediante movimientos sociales entre los que servían como aproximación las "redes de solidaridad” (AAT, 2004: 35) que se habían creado entre las personas vinculadas a las víctimas. Pues, como escribe Beck, "sin Estado y sin servicios públicos, no hay

${ }^{19}$ El discurso leído por Manjón alcanzaba uno de sus momentos más dramáticos cuando decía: "De lo que se está hablando, Señorías, es de la muerte y de las heridas de por vida padecidas por seres humanos, de pérdidas que nos han llenado de desolación y amargura en el mayor grado posible. ¿De qué se reían Señorías?, ¿qué jaleaban?, ¿qué vitoreaban en esta SU Comisión?” (ATT, 2004: 20).

20 "Nuestra llamada es una llamada a la ética, a la moral. A la ética de ustedes" (ATT, 2004: 26). "Nos parece que no han entendido, Señorías, qué significa para nosotros la palabra TRANSPARENCIA” (ATT, 2004: 30). 
seguridad (...) Sin opinión pública, sin democracia y sin sociedad civil, no hay legitimidad” (Beck, 2003: 42) ${ }^{21}$.

\section{Fotografías de autoridades y monumentos}

Como se ha adelantado anteriormente (\# 3), la recuperación de la normalidad en las estaciones de los atentados condujo a que, a partir del 9 de junio de 2004, fueran retirados ofrendas y carteles. Como ha explicado Truc (Truc, 2011: 207-227), y ya desde instancias oficiales, se puso en funcionamiento en la estación de Atocha lo que se denominó el Espacio de palabras. Un dispositivo electrónico en el que se podían dejar mensajes. De modo análogo, a través de la página web www.mascercanos.com, se podía continuar enviando mensajes.

Desde un punto de vista más solemne e institucional, y coincidiendo con el tercer aniversario de los atentados, el 11 de marzo de 2007, fue inaugurado por los reyes de España, Don Juan Carlos y Doña Sofía, junto a la estación de Atocha el Monumento homenaje a las víctimas del 11- $M$, una estructura discreta en el exterior a la que se puede acceder desde la estación de Atocha.

El interior, igualmente sobrio, es un espacio vacío, con una iluminación azulada. En las paredes de la bóveda se reproducen frases en diversos idiomas dirigidos a la memoria de las víctimas. El lugar invita al recogimiento. La solemnidad que se quiso otorgar al monumento incorpora la capacidad de simbolización, de hacer presente lo ausente (\# 4), a las víctimas, de la que el arte es capaz. En este caso, la documentación fotográfica no renuncia a compaginar la función comunicativa con la estética contribuyendo a transmitir el mensaje de conservación de la memoria que pretenden (Imagen 15).

Por nuestra parte, creemos que, pese a lo que escribe Sontag (\# 6), es posible que un nosotros comunitario aparezca en la mirada que dirigimos al dolor de los demás. Ejercida con capacidad artística, también la fotografía puede contribuir a esa simbolización. Una excelente foto de Jorge París, significativamente colocada a doble página entre las primeras del libro Archivo del duelo, logra en nuestra opinión cumplir este anhelo de la ciudad de Madrid y sus habitantes uniéndose al duelo por las víctimas. La imagen representa en un día algo oscuro la fuente sin duda más representativa de Madrid, en la que se halla la diosa Cibeles. Ella mira atentamente la lejanía. En sus brazos hay un pañuelo negro; enrollada en su cuello una bolsa negra como las que envolvían los cadáveres de los fallecidos. (Imagen 16).

${ }^{21}$ Las afirmaciones de Beck se encuadran en su crítica a la divisa del neoliberalismo de “sustituir la política y el Estado por la economía” (Beck, 2003: 38). 


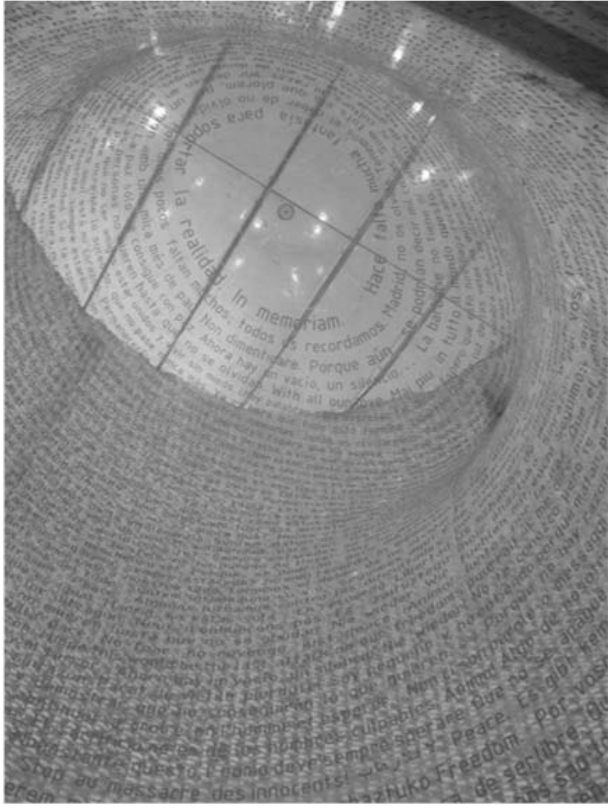

Imagen 15

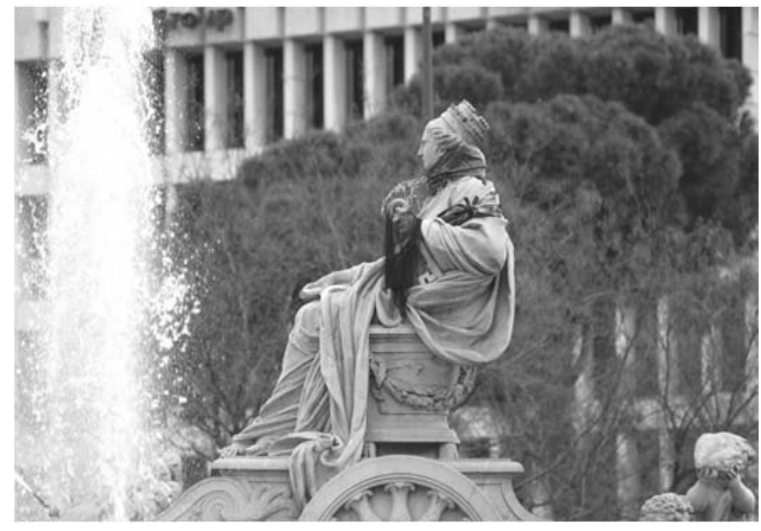

Imagen 16

\section{Conclusiones}

El uso que, tras los atentados del 11-M, se dio a la fotografía estuvo directamente relacionado con la relevancia y el significado que otorgaban a esta actividad los fotógrafos, la ciudadanía que se solidarizó con las víctimas y la Asociación 11-M. Afectados del Terrorismo ${ }^{22}$.

De modo inmediato, la fotografía cumplió funciones de información, recuerdo, y repudio de los atentados. En una perspectiva más pausada, la documentación fotográfica del 11-M ayuda a comprender cómo la ciudadanía actuó de un modo que ponía en evidencia, de modo tácito, su consideración de que la política que realizan los políticos profesionales debe tener en cuenta la opinión pública, al menos cuando, -tal como ocurrió con la exigencia de paz tanto ante la guerra de Irak del año 2003 como ante los atentados terroristas de 2004 en Madrid- las demandas son realizadas de forma mayoritaria. Tal cuestión pone de manifiesto como trasunto el debate

${ }^{22}$ No es objeto de este trabajo la documentación fotográfica en los medios de comunicación de masas. 
teórico sobre los conceptos de democracia directa y democracia representativa, así como las relaciones entre la democracia política a través de las instituciones estatales y la sociedad civil.

Por otra parte, el discurso leído en el Parlamento por Pilar Manjón, como portavoz de la asociación citada, evidenciaba los errores cometidos por el Estado en su cometido de racionalizar la vida colectiva. En efecto, el Estado había mostrado ineficacia en su obligación de defender la seguridad de las personas por lo que concierne a su vida, bienes, garantías jurídicas y a la propia imagen. Tal como denunció Manjón, la propia Comisión de investigación nombrada por el Parlamento habría subordinado la indagación de los hechos a criterios partidistas, defraudando con ello la confianza de los ciudadanos. Por otra parte, los atentados evidencian la realidad de la denominada sociedad del riesgo en la que el fenómeno terrorista, como una de sus manifestaciones, se aprovecha de la racionalización del sistema al mismo tiempo que debilita su capacidad de garantizar la seguridad de los ciudadanos. De ahí, que esté implícita la petición de mayor racionalización de la vida colectiva.

La documentación fotográfica deja constancia del modo en el que los atentados hicieron emerger un impulso comunitario compatible con la necesidad de rendir homenaje a las víctimas más inmediatas, es decir, a los muertos y a los heridos. Mostrar fotos de ellos en su vida cotidiana ejemplifica la demanda cívica de respetar, como un fin en sí mismo de la vida pública, la individualidad de las personas, frente a la cosificación y manipulación de las mismas.

La forma en la que los fotógrafos, profesionales o no, desarrollaron su labor está regida por el predominio de la función comunicativa sobre la poética. Sin embargo, ésta última cumplió una misión relevante al ser capaz, en algunos casos, de simbolizar la tragedia. Por otra parte, el modo en que se tomaron las imágenes está directamente relacionado con la situación representada, ya sea mediante fotografías hechas con discreción u otras en las que las personas deseaban que tomas frontales reflejaran los mensajes de tipo político -ante todo, de exigencia de información veraz, de ausencia de manipulación, de paz y de responsabilidad de los gobernantes- que trasmitían en manifestaciones realizadas en las calles.

\section{Bibliografía y filmografía}

Arabia, Sebastián (2010): Un largo invierno, Colmenar Viejo (Madrid), Suevia Films (Recurso electrónico, DVD).

Asociación 11-M. Afectados del Terrorismo (2005): Señor Presidente.... Discurso leído por Pilar Manjón en el Congreso de los Diputados el 15 de diciembre de 2004, Barcelona, Península (citado como AAT).

Barbadillo, Pedro et al. (2004): Madrid 11 M: todos íbamos en ese tren, Madrid, Docus. (Recurso electrónico, DVD).

Bauman, Zygmunt (2007): Arte, ¿líquido?, Madrid, Sequitur. 
Benjamin, Walter (1973): "La obra de arte en la época de su reproductibilidad técnica” en Discursos interrumpidos, I, Madrid, Taurus.

Beck, Ulrich. (2003): Sobre el terrorismo y la guerra, Barcelona, Paidós.

Campo Vidal, Manuel (2004): La revuelta de los móviles..., Canal Sur - TVC Lua Multimedia.

Cartier-Bresson, Henri (2003): Fotografiar del natural, Barcelona, Gustavo Gili.

Castells, Manuel (2003): La Galaxia Internet. Reflexiones sobre Internet, empresa y sociedad, Barcelona, Plaza y Janés.

Círculo de Praga (1970): Tesis de 1929, Madrid, Alberto Corazón editor.

Díaz-Mas, Paloma (2011): "Literatura para la vida: textos en los santuarios del 11 de marzo”, en Sánchez-Carretero, Cristina (ed.), El archivo del duelo, Madrid, CSIC, pp. 82-131.

Elías, Norbert (1990): Compromiso y distanciamiento, Barcelona, Península.

García Leal, José (2002): Filosofía del arte, Madrid, Síntesis.

Giddens, Anthony (1999): Consecuencias de la modernidad, Madrid, Alianza editorial.

Gubern, Román (1987): La mirada opulenta. Exploración de la iconosfera contemporánea, Barcelona, Gustavo Gili.

Kant, Emmanuel (1983): Fundamentación de la metafísica de las costumbres, Madrid, Espasa Calpe.

Ortega y Gasset, José (2004): "Ensayo de estética a manera de prólogo”, Obras completas, I, Madrid, Taurus y Fundación José Ortega y Gasset, pp. 664-680.

Ortiz, Carmen (2011): "Memoriales del atentado del 11 de marzo en Madrid" en Sánchez-Carretero, Cristina (ed.), El archivo del duelo, Madrid, CSIC, pp. 32-67.

Ortiz, Carmen (2013): "Pictures That Save, Pictures That Soothe: Photographs at the Grassroots Memorial to the Victims of the March 11, 2004 Madrid Bombings”, Visual Anthropology Review, 29 (1), pp 57-71, editado por la American Anthropological Association.

Reinares, Fernando (2014): ¡Matadlos! Quién estuvo detrás del 11-M y por qué se atentó en España, Madrid, Galaxia Gutenberg.

Reinares, Fernando (2012): "Memoria y desmemoria del subinspector Torrenteras", El País, 17/4/2012.

Sánchez Carretero, Cristina (coord.) (2011a): El archivo del duelo, Madrid, CSIC.

Sánchez Carretero, Cristina (2011b): "El Archivo del Duelo", en El archivo del duelo, Madrid, CSIC.

Simmel, Georg (1986): "Las grandes urbes y la vida del espíritu” (1903) en El individuo y la libertad, Ensayos de crítica de la cultura, Barcelona, Península.

Sontag, Susan (2010): Ante el dolor de los demás, Barcelona, Debolsillo.

Truc, Gérôme (2011): "Espacio de Palabras y rituales de solidaridad en Atocha”, en Sánchez-Carretero, Cristina (ed.), El archivo del duelo, Madrid, CSIC (pp. 206227).

Vallespín, Fernando (2005): “Prólogo”, en Blanco, Amalio, Rafael Del Águila y José Manuel Sabucedo (eds.) (2005): Madrid 11 M. Un análisis del mal y sus consecuencias, Madrid, Trotta. 


\section{Lista de imágenes}

En el caso de las ilustraciones existentes en el libro El archivo del duelo. (AD) Madrid: CSIC se señala la página del libro y su referencia documental.

Imagen $\mathrm{n}^{\circ}$, 1. Intervención de los equipos sanitarios del SAMUR. Estación de Atocha. Foto: Luis Magán (cedida por El País).

Imagen $n^{\circ}$, 2. Recogida de un cadáver. Foto: Luis Magán (cedida por El País).

Imagen $\mathrm{n}^{\circ}$, 3. Familiares de las víctimas llegando al pabellón sexto de Ifema, donde se lleva a cabo la identificación de los cadáveres. Foto: Uly Martin (cedida por El País).

Imagen $\mathrm{n}^{\mathrm{o}}$, 4. Tren reventado. Foto: Manuel Escalera (cedida por El País). Imagen $n^{\circ}, 5$. Atención a cadáveres. Foto: Luis Magán (cedida por El País).

Imagen $\mathrm{n}^{\circ}$, 6. Estación de Atocha. Foto: Cristina Sánchez-Carretero. AHF-MFMAD-FD-1266.

Imagen $\mathrm{n}^{\circ}$, 7. Estación de Atocha. Foto: Cristina Sánchez-Carretero. AHF-MFMAD-FD-995.

Imagen $n^{\circ}$, 8. Estación de Atocha. Foto: Cristina Sánchez-Carretero. AHF-MFMAD-FD-1051.

Imagen $n^{\circ}$, 9. Detalle de un montaje con esquelas. Foto: Tamara Ferreras. AHFMFM-AD-OB-475-C.

Imagen $\mathrm{n}^{\mathrm{o}}, 10$. Detalle del monumento homenaje a las víctimas en Leganés. Foto: Jorge París. AHF-MFM-AD-FD-2336.

Imagen $\mathrm{n}^{\circ}$, 11. Estación de El Pozo. Foto: Pedro Reina. AHF-MFM-AD-FD-2300. Imagen $\mathrm{n}^{\circ}, 12$. Concentración en Madrid. Foto: Jorge París. AHF-MFM-AD-FD2368.

Imagen $n^{\circ}$, 13. Concentración ante la sede del PP. Foto: Gorka Lejarcegi (cedida por El País).

Imagen $n^{\circ}$, 14. Estación de Atocha. Foto: Cristina Sánchez-Carretero. AHF-MFMAD-FD-1554

Imagen $\mathrm{n}^{\circ}$, 15. Rafael García Alonso. Madrid. 25 de marzo de 2007

Imagen $\mathrm{n}^{\mathrm{o}}$, 16. Fuente de La Cibeles, Madrid. Foto: Jorge París. AHF-MFM-ADFD-2344. 